\title{
The subjective well-being of day labourers in South Africa: The role of income and geographical location
}

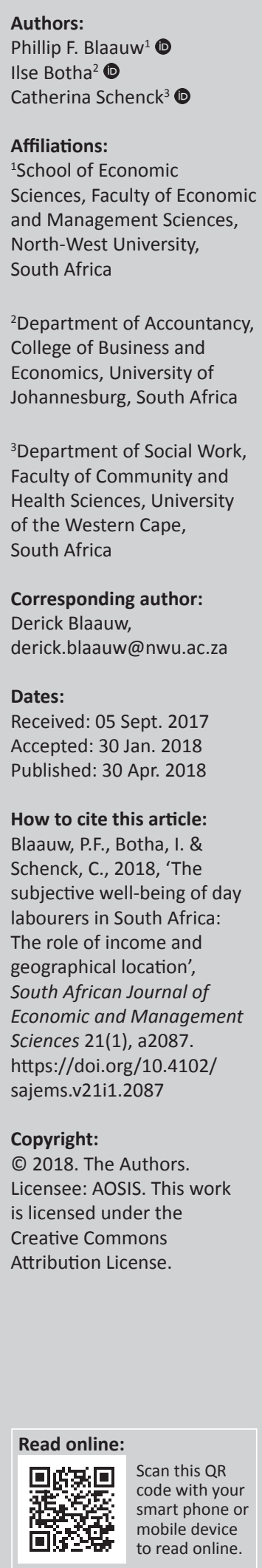

Background: The informal economy in South Africa provides employment to large numbers of people who would otherwise have no opportunity to earn a living. Yet informal activities, such as day labouring, generate highly uncertain returns. Although it seems reasonable to conclude that day labourers would be dissatisfied with their lives, this is not necessarily the case as several factors contribute to people's subjective well-being.

Aim: This study is in response to a call for more research on the subjective well-being of marginalised groups in South Africa's informal labour market.

Setting: The day labour market in South Africa, whose members congregate at hiring sites hoping to be picked up by passers-by in need of temporary, casual workers.

Methods: Using Sen's Capability Approach, the study builds on earlier research conducted on the general well-being of day labourers in South Africa, with specific focus on their subjective well-being and geographical location. The results from a countrywide survey of 3830 day labourers were used in a regression analysis to compare the subjective well-being among day labourers across the nine provinces of South Africa.

Results: There are statistically significant differences in the well-being of day labourers across the nine provinces. Economic variables play a role in both objective and subjective measures of well-being, while attitudinal and comparison variables are significant for the objective and subjective measures, respectively.

Conclusions: Although they have to operate in harsh conditions, day labourers in South Africa display agency by choosing to migrate to richer provinces in search of greater economic opportunity and reward. However, these potential gains are often negated by increased levels of competition and thus depressed wage levels. How to nurture marginalised groups' abilities to exercise agency and take more control of their lives represents fertile ground for researchers in future.

\section{Introduction}

It is commonly believed that people who are unable to find employment in the formal sector and need to fall back on low-skilled, informal work like day labouring and waste picking experience both financial and emotional deprivation. While the financial returns from these informal activities are often uncertain or inadequate, it should not be a foregone conclusion that the people performing this type of work are unhappy. There are a number of factors, other than straight earning power, that can possibly contribute to their relative satisfaction with life or their 'subjective well-being'.

Subjective well-being (SWB), together with the factors contributing to the phenomenon, constitutes a highly complex field of study. Diener, Oishi and Lucas (2002:63) broadly define subjective well-being as 'a person's cognitive and affective evaluations of his or her life'. The cognitive dimension relates to a person's views about their life in general as well as particular aspects of their life, such as work and personal relationships.

Ebrahim, Botha and Snowball (2013) and Hirata (2011) consider the relationship between happiness and absolute income to be one of the most important topics covered in the literature. Biswas-Diener and Diener (2001) expected people living in abject poverty in the slums of Calcutta (India) to be 'miserable'. Surprisingly, the authors found people with relatively high levels of subjective well-being, in spite of their impoverishment. Blaauw et al. (2015) were similarly surprised to find that the majority of the participants in their study on landfill waste pickers in South Africa's Free State province were not filled with despair - which would have equated with low levels of subjective well-being. 
The fact that the results of Blaauw et al. (2015) were unexpected lends weight to the conclusion reached by Cramm, Møller and Nieboer (2010) that subjective well-being among marginalised groups in the informal sector in South Africa is not well understood and receives sparse treatment in the literature. This gap in the literature is not surprising, since research on informal labour market activities, such as waste picking and day labouring, is difficult to conduct for various reasons. For example, day labour hiring sites in existence today may be gone tomorrow.

The study outlined in this paper expands on previous research by Blaauw et al. (2013) (which looked at well-being in a general sense) by focusing specifically on the subjective wellbeing of day labourers and by introducing a new dimension: day labourers' geographical location, which is influenced by migration patterns. Migration and geographical differences are important considerations in a study of subjective wellbeing as they reflect day labourers' willingness to move from poorer to richer provinces in pursuit of greater economic opportunity and choice.

Within this construct we used Sen's Capability Approach (CA) to contextualise day labourers' ability (or inability) to fully realise their potential and to achieve a satisfying existence. In line with the suggestion of Alatartseva and Barysheva (2015:37), we specifically measured day labourers' material well-being in terms of the level and stability of income and other relevant indicators. Personal income, we argue, is especially important for subjective well-being among poor people (Cummins 2000; Diener et al. 1993). The results from the first (and up until now only) countrywide survey of day labourers in South Africa were used as the basis for the study.

The paper uses the Diener et al. (2002) definition of subjective well-being as the point of departure and then focuses specifically on the paradigm posed by Alatartseva and Barysheva (2015), which distinguishes between subjective and objective well-being. Whereas objective well-being uses quantifiable measures to determine a person's quality of life or well-being (such as access to water, electricity, education, and so on), subjective well-being relates to a person's own perceptions of their life.

While making an important and more nuanced contribution to the literature on subjective well-being among marginalised groups of people, the findings from this study also offer a number of practical insights into the factors that influence the ability of marginalised groups in the labour force, such as day labourers, to take control of their lives. Armed with this knowledge, policymakers and other members of society will be in a better position to take steps to help these people live more meaningful lives, as envisaged by Sen $(1999,2003)$.

The rest of the paper is structured as follows. The next section examines Sen's Capability Approach, which provides the theoretical framework for the discussion. Subsequent sections provide a brief overview of the literature on day labouring and subjective well-being in South Africa, the survey methodology and results, the model selection and empirical analysis, the key conclusions, and avenues for further research.

\section{Theoretical framework: Sen's Capability Approach}

Sen's (1999) Capability Approach (CA) was used in this study as the theoretical framework to assess the subjective wellbeing of day labourers in South Africa. Robeyns (2006) views the CA as a normative framework for evaluating and assessing the opportunities, freedoms and capabilities of people to make choices and live valuable lives, which then contributes to their well-being. This includes aspirations to be nourished, to be literate, to have shelter, and to experience good health, selfrespect and dignity (Alkire \& Deneulin 2002; Robeyns 2005).

According to Sen (1999), the freedom to lead different types of life is reflected in a person's capability set, which depends on factors such as educational level, health status and community involvement.

An important component in a person's capability set is 'agency', which is the ability to pursue and realise one's own goals. The activity of day labouring is an example of agency in action. Faced with the opportunity and freedom to do so, day labourers choose to stand on street corners every day, often having migrated from other provinces and leaving their families behind. Sen (1999) explains that being free to make choices may be directly conducive to well-being. Although the income earned by day labourers places them in the survivalist category (Blaauw, Louw \& Schenck 2006), the freedom to choose how and where they work might provide them with a sense of achievement. This phenomenon will be explored more fully in this paper in the context of day labourers' choice of geographical location and the impact thereof on subjective well-being.

\section{Brief literature overview: Day labouring and subjective well-being in South Africa}

As is the case in many other parts of the world, day labouring is on the increase in South Africa (Theodore et al. 2015). In countries like the United States, it is mostly immigrants (almost exclusively from Latin America) who use day labouring as a means of gaining a foothold in the economy (Valenzuela et al. 2006). In South Africa, however, day labouring is the last resort for many who have lost their jobs or have been unable to secure employment in the formal economy. Immigrants from the rest of Southern Africa compete with South African day labourers for the available casual employment on offer (Theodore et al. 2015).

Day labourers are among the most marginalised and vulnerable groups in the South African informal economy (Theodore et al. 2015). Every day tens of thousands of men (and occasionally women) gather at hiring sites in towns and 
cities, seeking employment for the day or for a limited period (Harmse, Blaauw \& Schenck 2009). They have no guarantee of being hired on any of the six to seven days per week that they congregate at these sites. Day labour work is decidedly uncertain, with many labourers working in sub-standard conditions (Theodore, Valenzuela \& Meléndez 2009). Long spells of not being hired and consequently not earning an income are expected to negatively affect their level of subjective well-being.

The economics literature provides a number of excellent reviews on the general determinants of well-being. ${ }^{1}$ However, literature on the subjective well-being of informally employed people in the labour market is much more meagre - both generally and in relation to South Africa. Blaauw et al. (2013) conducted an exploratory study on the possible determinants of subjective well-being among South Africa's informally employed, using day labouring as a case study. The results from this study corroborated the importance of employment and income for both the objective and subjective well-being of those living in abject poverty (Blaauw et al. 2013). However, changes in income and the quality of jobs are also tied to the location of the hiring sites within an urban or rural context. Large urban areas are located in those provinces where economic activity is more intensive. Differences in the levels of economic activity and growth as well as income differentials between the various provinces are a driving force behind the internal migration of day labourers in South Africa. Recent findings by Statistics South Africa (2014:31) give impetus to this deduction. In 2006, the highest levels of poverty were found in Limpopo (74.4\%), followed closely by the Eastern Cape (69.5\%) and KwaZulu-Natal (69.1\%). By contrast, poor people were in the minority in the Western Cape (36.9\%) and Gauteng (32.4\%) (Statistics South Africa 2014:31). It therefore comes as no surprise that the majority of the day labourers in the Western Cape at the time of the survey were from the Eastern Cape.

With migration on the rise, location warrants more attention. Conceptually, the precise impact of location on happiness is difficult to determine. More densely populated urban areas theoretically provide more opportunities to earn an income, and this could plausibly increase levels of well-being. The other side of the coin, though, is that increased levels of migration can lead to an oversupply of day labour and hence a reduction in income and consequently well-being.

The question is, where do day labourers stand, especially given the precarious market conditions under which they operate? Available data suggest that day labourers, similar to other urban migrants, come to the wealthier provinces to find work. However, high levels of competition could result in many people's expectations exceeding their actual ability to achieve a better life. Therefore, disappointment might set in and erode their subjective well-being.

Another study that dealt with the impact of geographical location on subjective well-being among migrants was that of 1.See, for example, the work of Frey and Stutzer (2002) and Dolan, Peasgood and White (2008)
Knight and Gunatilaka (2008). The authors set out to explain why the mean happiness score of rural-to-urban migrants in China is lower than that of those who stay behind in the countryside. They postulated that the aspirations of migrants rise when they get to the cities, but then their achievements fall short of expectations. South Africa has also experienced significant rural-to-urban migration, with many day labourers in urban areas having originated in South Africa's rural districts (Harmse et al. 2009).

\section{Survey methodology}

\section{Sampling approach}

On the basis of the protocol established by Valenzuela et al. (2006) in their nation-wide study of day labourers in the United States, the researchers conducted a census of day labourers in the various cities and towns in South Africa in 2005 and 2006. The researchers recorded the names of the streets where the day labourers congregated and counted the number of day labourers at each site. ${ }^{2}$

An important inference to be made is that in a census of this nature, the numbers might not reflect the total size of the day labour workforce. For example, exclusions would be workers who were hired prior to the count and workers who regularly used the hiring site but for some reason did not search for work on the day in question (Valenzuela et al. 2006:4). There were close to 1000 locations in South Africa where people were picked up, while a minimum of 45000 , mostly African men, stood at these sites looking for work each day. ${ }^{3}$

Table 1 provides a summary of the estimated number of day labourers in the nine provinces in South Africa during the 2005-2006 research and counting process, compared with the provincial population distribution at the time.

Table 1 shows that the provinces with the highest number of day labourers were the wealthier ones (Gauteng, Western Cape and KwaZulu-Natal). The interviews conducted with the day labourers confirmed these provinces as the most popular destinations for foreign and South African day labourers alike.

TABLE 1: Estimated number of day labourers in the nine provinces of South Africa, 2005-2006.

\begin{tabular}{llll}
\hline Province & $\begin{array}{l}\text { Number of day } \\
\text { labourers }\end{array}$ & $\begin{array}{l}\text { \% of total day } \\
\text { labour population }\end{array}$ & $\begin{array}{l}\text { \% of projected total } \\
\text { provincial population }\end{array}$ \\
\hline Western Cape & 8839 & 19.7 & 10 \\
Eastern Cape & 4379 & 9.8 & 14.9 \\
Northern Cape & 1790 & 4.0 & 1.9 \\
Free State & 5670 & 12.6 & 6.2 \\
KwaZulu-Natal & 7247 & 16.1 & 20.5 \\
North West & 3390 & 7.6 & 8.1 \\
Gauteng & 9948 & 22.2 & 19.4 \\
Mpumalanga & 2933 & 6.5 & 6.9 \\
Limpopo & 700 & 1.6 & 12 \\
\hline Total & 44896 & 100 & 100 \\
\hline
\end{tabular}

Source: Statistics South Africa, 2006, Mid-year population estimates, South Africa 2006 viewed 13 August 2016, from http://www.statssa.gov.za/publications/P0302/P03022006.pdf

2.Given the length restrictions for this paper, see Blaauw (2010) for a detailed discussion on the choice of day and seasonal considerations and other operational arrangements.

3.See Harmse et al. (2009) for all the locations at municipal level. 
Regarding the sampling procedure, the capitals of all provinces and important hubs in the rural areas had to be covered proportionally according to the number of day labourers present. A cluster sampling approach was used (Rubin \& Babbie 1997), with clustering taking place in terms of both the number of day labourers interviewed in each centre and the size of the various hiring sites. Had this not been done, there would have been an over-representation of rural versus urban areas and big hiring sites versus small hiring sites.

Aiming for a representative sample size of around 10\% (to control for possible sampling error) meant that between 2500 and 4000 interviews had to be conducted across South Africa (De Vos et al. 2004:200). The fieldwork commenced in February 2007 and was concluded at the beginning of $2008 .{ }^{4}$ A total of 3830 questionnaires were accepted for the analysis, representing $8.5 \%$ of the estimated research population.

From an ethical standpoint, it was crucial not to deprive any day labourer of work because he was participating in the interview process. In some cases, therefore, interviews were not conducted. This meant that the data had to be cleaned so that a cross-sectional regression analysis could be conducted. Thereafter, the size of the sample was 2645.

\section{Survey results: Descriptive statistics on day labourers in South Africa}

The following descriptive statistics were compiled on the participants in the study.

\section{Demographic characteristics and employment history}

Table 2 provides a summary of the basic demographic characteristics of the day labourers who participated in the survey.

The survey results for gender and age of the day labourers reflect the racial composition of the broader informal sector in South Africa (Saunders 2005). Notably, the age distribution highlights the persistent unemployment and under-employment among the country's youth (Statistics South Africa 2015). In addition, each day labourer supported an average of four people, excluding themselves. At least 170000 people survived on the income generated through this type of informal employment.

\section{Income earned}

A key element in the study of subjective well-being among day labourers is the income that they earn (Blaauw et al. 2013). Table 3 shows the average income earned by survey participants in a 'good week' and 'bad week' respectively, across the different provinces.

4.Although this makes the data set 10 years old, it still remains the only data available. Furthermore, the extent of day labouring is expanding continuously, making it important to utilise the available data while the follow-up survey is currently being conducted.
TABLE 2: Demographic profile and employment history of day labourers in South Africa, 2007-2008.

\begin{tabular}{|c|c|c|}
\hline Variable & Category & Value \\
\hline \multirow[t]{4}{*}{ Country of origin } & South Africa & $85 \%$ \\
\hline & Zimbabwe & $9.50 \%$ \\
\hline & Mozambique & $2.60 \%$ \\
\hline & Lesotho & $1.40 \%$ \\
\hline \multirow[t]{2}{*}{ Gender } & Male & $96.40 \%$ \\
\hline & Female & $3.60 \%$ \\
\hline \multirow[t]{3}{*}{ Race } & African & $92 \%$ \\
\hline & Coloured & $7.30 \%$ \\
\hline & White and Indian & $0.70 \%$ \\
\hline \multirow[t]{3}{*}{ Age } & Younger than 30 & $47.10 \%$ \\
\hline & Between 30 and 35 & $22.90 \%$ \\
\hline & 35 and older & $30 \%$ \\
\hline \multirow[t]{6}{*}{ Education } & No schooling & $6 \%$ \\
\hline & Some primary schooling & $18.70 \%$ \\
\hline & Completed primary schooling & $9.20 \%$ \\
\hline & Some secondary schooling & $48.70 \%$ \\
\hline & Completed secondary schooling & $14.80 \%$ \\
\hline & Post-school qualification & $1.90 \%$ \\
\hline \multirow[t]{5}{*}{ Marital status } & Never married/single & $56.10 \%$ \\
\hline & Married & $26 \%$ \\
\hline & Living with a partner & $9.90 \%$ \\
\hline & Separated/divorced & $5.60 \%$ \\
\hline & Widowed & $1.50 \%$ \\
\hline Dependants & Average & 4 \\
\hline Number of children & Average & 2 \\
\hline \multirow[t]{2}{*}{ Living conditions } & Living with their family & $52 \%$ \\
\hline & $\begin{array}{l}\text { Living in a permanent structure such as } \\
\text { a brick house }\end{array}$ & $32 \%$ \\
\hline Employment history & Had a full-time job before & $51 \%$ \\
\hline \multirow{4}{*}{$\begin{array}{l}\text { Hired more than three } \\
\text { times by same employer } \\
\text { as day labourer }\end{array}$} & It never happens & $10 \%$ \\
\hline & It seldom happens & $50 \%$ \\
\hline & It happens sometimes & $25 \%$ \\
\hline & It happens often & $15 \%$ \\
\hline
\end{tabular}

TABLE 3: Average income earned in a good week and a bad week by day labourers per province, 2007-2008 (ZAR).

\begin{tabular}{lcc}
\hline Province & Good week & Bad week \\
\hline Gauteng & 410 & 168 \\
Mpumalanga & 343 & 149 \\
KwaZulu-Natal & 407 & 162 \\
Eastern Cape & 365 & 135 \\
Limpopo & 150 & 53 \\
North West & 303 & 159 \\
Free State & 208 & 90 \\
Northern Cape & 288 & 121 \\
Western Cape & 554 & 228 \\
\hline
\end{tabular}

However, merely looking at the averages does not tell the full story. Harmse et al. (2009) observed differences in attitude about income-earning prospects among day labourers in the various cities and towns across South Africa. An analysis of income earned at a more disaggregated level is also necessary. Table 4 and Table 5 disaggregate the distribution of income earned by day labourers in South Africa, in a good and bad week respectively, at the provincial level.

Table 4 reveals that in (what survey participants perceived as) good weeks, the majority of day labourers earned in excess of ZAR 400 per week in 2007. This applied to South Africa as a whole as well as to six of the nine provinces. Income levels in 
TABLE 4: Distribution of income earned in a good week by day labourers per province, 2007 (percentages).

\begin{tabular}{|c|c|c|c|c|c|c|c|}
\hline Variable & Less than ZAR 100 & ZAR 100-ZAR 199 & ZAR 200-ZAR 299 & ZAR 300-ZAR 399 & More than ZAR 400 & Not specified & Total \\
\hline Gauteng & 2.3 & 6.8 & 9.5 & 24 & 53.4 & 4 & 100 \\
\hline Mpumalanga & 8.7 & 23.8 & 9.7 & 1.8 & 51.3 & 4.7 & 100 \\
\hline KwaZulu-Natal & 0.9 & 19.5 & 28.7 & 14.4 & 31.1 & 5.4 & 100 \\
\hline Eastern Cape & 5.3 & 17.4 & 17.8 & 21.3 & 34.6 & 3.6 & 100 \\
\hline Limpopo & 14.4 & 61.3 & 19.8 & 0.9 & 1.8 & 1.8 & 100 \\
\hline North West & 11.7 & 31 & 10.9 & 10.5 & 31.5 & 4.4 & 100 \\
\hline Free State & 21.1 & 17.7 & 30.6 & 23.2 & 3.7 & 3.7 & 100 \\
\hline Northern Cape & 8.4 & 27.3 & 25.1 & 10.5 & 15.3 & 13.4 & 100 \\
\hline Western Cape & 1.1 & 7.2 & 17.8 & 13.2 & 56.8 & 3.9 & 100 \\
\hline South Africa & 6.1 & 16 & 18.6 & 16.6 & 38.2 & 4.5 & 100 \\
\hline
\end{tabular}

TABLE 5: Distribution of income earned in a bad week by day labourers per province, 2007 (percentages).

\begin{tabular}{|c|c|c|c|c|c|c|}
\hline Variable & ZAR 0-ZAR 100 & ZAR 101-ZAR 200 & ZAR 201-ZAR 300 & ZAR 301-ZAR 400 & More than ZAR 400 & Total \\
\hline Gauteng & 44.3 & 35.4 & 10.8 & 4.8 & 4.7 & 100 \\
\hline Mpumalanga & 47.6 & 24.6 & 17.3 & 6.5 & 4.0 & 100 \\
\hline KwaZulu-Natal & 62.9 & 11.7 & 10.4 & 4.4 & 10.6 & 100 \\
\hline Eastern Cape & 57.5 & 23.5 & 11.8 & 5.0 & 2.2 & 100 \\
\hline Limpopo & 99.0 & - & - & - & 1.0 & 100 \\
\hline North West & 53.0 & 17.8 & 12.3 & 4.6 & 12.3 & 100 \\
\hline Free State & 71.2 & 23.6 & 3.4 & 1.0 & 0.8 & 100 \\
\hline Northern Cape & 62.1 & 26.0 & 8.5 & 1.7 & 1.7 & 100 \\
\hline Western Cape & 40.8 & 16.7 & 15.0 & 10.6 & 16.9 & 100 \\
\hline South Africa & 53.3 & 22.3 & 11.1 & 5.4 & 7.9 & 100 \\
\hline
\end{tabular}

good weeks were clearly lower in the Free State, Northern Cape and Limpopo provinces.

Table 5 reveals only one income category (less than ZAR 100 per week) applicable to the majority of day labourers in all provinces during a bad week. Again, it seems that the situation in the Free State, Northern Cape and Limpopo provinces was worse than at the national level. This in turn appears to mirror general inequality patterns in South Africa and highlights relative provincial economic performance at the time. This would have important implications for the power relations within the competitive day labour market. Given the persistent depressed economic conditions in these provinces, day labourers had virtually no power to negotiate wages with prospective employers (Theodore et al. 2015). Theory would suggest that these factors have an undeniably negative influence on the subjective well-being of day labourers in South Africa (Sen 1999, 2003). This deduction constitutes one of the key building blocks for the model selection and empirical analysis described in the next section.

\section{Model selection and empirical analysis \\ Research method}

To investigate the impact of geographical location on the well-being of day labourers in South Africa, we employed a cross-sectional analysis using dummy variables for the nine provinces - which the exploratory study by Blaauw et al. (2013) did not make provision for. The purpose of these dummy variables was to account for differences in the wellbeing of day labourers between provinces. The model can be specified as follows: $y_{i}=\beta X_{i}+\mu D 1_{i}+\mu D 2_{i} \ldots .+\mu D N_{i}+\mu_{i}$

[Eqn 1]

$y_{i}$ is the dependent variable for a certain cross-section $(i)$; $\mathrm{D}$ is the subgroup in the cross-section - in this case, a province and $\beta$ is a $k \times 1$ vector of parameters to be estimated on the $k \times 1$ observations of the explanatory variables $(X) ; i$ is $1, \ldots \mathrm{N}$ (Brooks 2008). As a robustness check, we also estimated a cross-sectional panel model. The results corroborated our findings. However, given that $t=1$ in the panel analysis, we only report on the cross-sectional analysis in the ensuing paragraphs.

\section{Model specification}

Two functions were specified, namely a subjective and an objective function. The difference between these two functions was the dependent variable, which was a proxy for the subjective and objective measure of well-being. We based our choice of the dependent variable for the subjective function on the work of Knight, Song and Gunatilaka (2009), which concluded that satisfaction with household income is one possible measure of subjective well-being (SWB). The dependent variable for the subjective function was the satisfaction of the day labourer with their level of income (Is your income worse, or good or better than expected?). This was a binary type variable with two categories $(D=0$ if it is worse; $\mathrm{D}=1$ if it is good or better than expected). The variable may, at first glance, appear to be merely an income satisfaction variable. However, there is an argument that even if the actual income is as good as expected, it does not necessarily mean that the individual is satisfied or happy with it. The socioeconomic construct of day labourers potentially counters this conclusion.

Since day labouring is a survival strategy, traditional economic considerations such as optimality and wealth creation do not 
feature directly. Therefore, within this unique context, the dependent variable does not merely constitute a comparison between expectations and reality; indeed, it is a measure of subjective well-being among labourers.

Day labourers are well aware that the supply of their type of work is increasing constantly while the demand is not keeping pace. The proverbial cake must therefore be shared among an ever-growing day labour force, while a constantly diminishing level of real earnings is expected (Blaauw et al. 2013). This view is supported by the fact that reservation wages are steadily falling in many informal labour markets (Theodore et al. 2009). If a day labourer says his or her income is as good as or better than expected, it shows a level of subjective satisfaction, given the typical uncertainty and income variances in the day labour market. The fact that this was a recurring theme in discussions with the survey participants convincingly motivates the use of this variable in the subjective function. We therefore argue that the dependent variable does not merely mean a comparison between expectations and reality; it is a measure of subjective well-being among labourers.

According to the literature, income is a very important indicator of well-being in poor communities (Diener et al. 1993, 2002). The dependent variable for the objective function was the log of the best wage earned per day. When day labourers achieve their best income levels, it brings about a feeling of happiness and improved well-being (Blaauw et al. 2013).

Table 6 and Table 7 provide descriptive statistics of the dependent variables for the objective and subjective functions of the two models.

The two dependent variables were the 'Best wage' and 'Good or better expectations', respectively. The highest mean best wage was in the Western Cape, followed by KwaZulu-Natal and Gauteng. The maximum best wages recorded were in KwaZulu-Natal, Gauteng and Limpopo. The lowest mean best wage was in the Free State. There was high dispersion in the data, as revealed in the large differences between the minimum and maximum best wages per province as well as the high kurtosis values.
For the subjective measure (looking at the percentage of total day labourers per province), the Eastern Cape recorded the most labourers with good or better income expectations, followed by Gauteng and the Western Cape. Together these accounted for about $50 \%$ of the sample per province. Limpopo recorded the lowest number of labourers satisfied with their income (only 3\%), followed by the Free State and KwaZulu-Natal.

Table 7 indicates the best wage divided into categories. In addition, it shows the number of day labourers whose income expectations were worse, or good or better, according to these wage categories. It is evident that the first two best wage categories were dominant with lower numbers recorded as the income levels increased. Furthermore, it is in these two best wage categories that the income expectations were also the worst. Looking at the full sample, $58 \%$ of day labourers were not satisfied with their income as opposed to $42 \%$ who were satisfied.

The basic approach to specifying a well-being function is to include basic variables, conventional economic variables, comparison variables, community variables and attitudinal variables as explanatory variables (Cummins 2000; Kingdon \& Knight 2004; Knight et al. 2009). The following variables from the day labourer survey were used and classified according to these broad categories:

TABLE 7: Descriptive statistics for best wage in categories.

\begin{tabular}{|c|c|c|c|c|}
\hline \multirow[t]{2}{*}{ Best wage in ZAR } & \multirow[t]{2}{*}{ Variable } & \multicolumn{2}{|c|}{ Expectations } & \multirow[t]{2}{*}{ Total } \\
\hline & & Worse & Good or better & \\
\hline \multirow[t]{2}{*}{ 0-99 } & Count & 745 & 334 & 1079 \\
\hline & $\%$ & 28.17 & 12.63 & 40.79 \\
\hline \multirow[t]{2}{*}{ 100-199 } & Count & 746 & 561 & 1307 \\
\hline & $\%$ & 28.20 & 21.21 & 49.41 \\
\hline \multirow[t]{2}{*}{ 200-299 } & Count & 23 & 128 & 151 \\
\hline & $\%$ & 0.87 & 4.84 & 5.71 \\
\hline \multirow[t]{2}{*}{ 300-399 } & Count & 9 & 63 & 72 \\
\hline & $\%$ & 0.34 & 2.38 & 2.72 \\
\hline \multirow[t]{2}{*}{$400-499$} & Count & 2 & 16 & 18 \\
\hline & $\%$ & 0.08 & 0.60 & 0.68 \\
\hline \multirow[t]{2}{*}{$500-599$} & Count & 3 & 9 & 12 \\
\hline & $\%$ & 0.11 & 0.34 & 0.45 \\
\hline \multirow[t]{2}{*}{$600-699$} & Count & 0 & 6 & 6 \\
\hline & $\%$ & 0.00 & 0.23 & 0.23 \\
\hline \multirow[t]{2}{*}{ Total } & Count & 1528 & 1117 & 2645 \\
\hline & $\%$ & 57.77 & 42.23 & 100.00 \\
\hline
\end{tabular}

TABLE 6: Descriptive statistics for the dependent variables.

\begin{tabular}{|c|c|c|c|c|c|c|c|c|c|c|}
\hline Variable & Eastern Cape & Free State & Gauteng & KwaZulu-Natal & Limpopo & Mpumalanga & Northern Cape & North West & Western Cape & Full sample \\
\hline \multicolumn{11}{|c|}{ Objective measure: Best wage } \\
\hline Mean (ZAR) & 106.26 & 81.80 & 132.52 & 136.40 & 92.53 & 89.97 & 91.51 & 93.42 & 155.53 & 121.25 \\
\hline Median (ZAR) & 95 & 80 & 150 & 100 & 70 & 80 & 80 & 90 & 120 & 100 \\
\hline Maximum (ZAR) & 400 & 300 & 501 & 600 & 500 & 400 & 450 & 220 & 450 & 600 \\
\hline Minimum (ZAR) & 20 & 20 & 25 & 40 & 40 & 30 & 25 & 40 & 30 & 20 \\
\hline Standard deviation & 50.69 & 30.85 & 49.69 & 107.99 & 55.01 & 49.91 & 59.04 & 37.78 & 83.07 & 71.37 \\
\hline Skewness & 1.39 & 2.01 & 2.32 & 2.58 & 4.63 & 3.41 & 2.63 & 0.68 & 1.03 & 2.47 \\
\hline Kurtosis & 6.78 & 14.60 & 16.81 & 9.67 & 33.32 & 19.89 & 13.34 & 2.81 & 3.54 & 12.44 \\
\hline Observations & 306 & 212 & 681 & 366 & 95 & 166 & 159 & 165 & 495 & 2645 \\
\hline \multicolumn{11}{|c|}{ Subjective measure: Good or better expectations } \\
\hline Number & 166 & 39 & 352 & 112 & 3 & 59 & 74 & 61 & 251 & 1117 \\
\hline$\%$ of total & 54.25 & 18.40 & 51.69 & 30.60 & 3.16 & 35.54 & 46.54 & 36.97 & 50.71 & 42.23 \\
\hline
\end{tabular}


The basic demographic variables are standard throughout the literature. They include gender, education, marital status and age. In this survey, age was categorised and was not used as a continuous variable. See Tables 8-11 below.

The comparison between current income and past circumstances and aspirations formed the subjective perception of the participants of their financial situation. These comparison variables were primarily a comparison of an individual at different times, or with other day labourers that the participant knew.

The attitudinal variables were included to control for behaviour, which affected subjective well-being. The three attitudinal variables reflected the psychological state of mind or attitude shaping their perception of their job or situation. The community variables captured the unobserved provincial differences, which could have been related to government funding, infrastructure in rural areas, governance, environment and culture (Knight et al. 2009). The variables were grouped according to the nine provinces in South Africa.

\section{Estimation results}

The objective and subjective functions were estimated on a cross-section with 2645 (n) observations within the dummy variable framework. The two-stage least-squares method (2SLS) was used in the objective function, but due to the

TABLE 8: Basic demographic variables.

\begin{tabular}{|c|c|c|c|}
\hline Variable & $\begin{array}{l}\text { Definition/question } \\
\text { in survey }\end{array}$ & $\begin{array}{l}\text { Expected sign } \\
\text { of coefficient }\end{array}$ & $\begin{array}{l}\text { A priori reasoning for } \\
\text { expected sign }\end{array}$ \\
\hline African & Race & Irrelevant & Most day labourers are African. \\
\hline Male & Gender & Irrelevant & Most day labourers are male. \\
\hline Primary & $\begin{array}{l}\text { Completed } \\
\text { primary school }\end{array}$ & + & $\begin{array}{l}\text { Education at primary level does } \\
\text { not affect SWB negatively. }\end{array}$ \\
\hline Secondary & $\begin{array}{l}\text { Did not complete } \\
\text { secondary school }\end{array}$ & + & $\begin{array}{l}\text { Education at secondary level, } \\
\text { not completed, does not affect } \\
\text { SWB negatively. }\end{array}$ \\
\hline Complete & $\begin{array}{l}\text { Completed } \\
\text { secondary school }\end{array}$ & - & $\begin{array}{l}\text { People expect more from life } \\
\text { when they have completed } \\
\text { secondary school. }\end{array}$ \\
\hline Married & Marital status & + & $\begin{array}{l}\text { Knight et al. (2009) found that } \\
\text { people who are married are } \\
\text { happier. }\end{array}$ \\
\hline Divorced & Marital status & - & $\begin{array}{l}\text { Botha and Booysen (2013) } \\
\text { found that in South Africa } \\
\text { married people are more } \\
\text { satisfied than those from all } \\
\text { other marital status groups. }\end{array}$ \\
\hline Twenties & Age & - & $\begin{array}{l}\text { The younger the day labourer, } \\
\text { the less happy he or she is } \\
\text { expected to be, since he or she } \\
\text { is looking for a better life } \\
\text { (Gonzo \& Plattner 2003:47). } \\
\text { Older people, on the other } \\
\text { hand, are negative because } \\
\text { they know it is difficult to enter } \\
\text { the formal job market, which } \\
\text { gives rise to further feelings } \\
\text { of despair and self-doubt. }\end{array}$ \\
\hline Thirties & Age & - & See above. \\
\hline Forties & Age & - & See above. \\
\hline Over 50 & Age & \pm & $\begin{array}{l}\text { See above; alternatively, they } \\
\text { have made peace with their } \\
\text { circumstances. This is an } \\
\text { adaptation of the u-curve for } \\
\text { subjective well-being with age. }\end{array}$ \\
\hline
\end{tabular}

binary nature of the dependent variable for the subjective function a probit model was selected as the most appropriate model for this function.

The income variable, log of the wage in a good week (GOODWEEK), was instrumented because of endogeneity problems that occur with income when estimating SWB functions (Kingdon \& Knight 2004; Senik 2005). The endogeneity test indicated that the income variable (GOODWEEK and the change in income) was endogenous in the objective function, but not in the subjective function.

TABLE 9: Economic variables.

\begin{tabular}{|c|c|c|c|}
\hline Variable & $\begin{array}{l}\text { Definition or } \\
\text { question in survey }\end{array}$ & $\begin{array}{l}\text { Expected sign } \\
\text { of coefficient }\end{array}$ & $\begin{array}{l}\text { A priori reasoning for } \\
\text { expected sign }\end{array}$ \\
\hline Good week & $\begin{array}{l}\text { The income variable } \\
\text { is the log of the wage } \\
\text { in a good week }\end{array}$ & + & $\begin{array}{l}\text { If a day labourer earned a good } \\
\text { week's wage, he or she would } \\
\text { probably feel positive. }\end{array}$ \\
\hline Full-time & $\begin{array}{l}\text { Were you previously } \\
\text { employed full-time? }\end{array}$ & - & $\begin{array}{l}\text { The wage income in the formal } \\
\text { economy will probably be much } \\
\text { higher, and therefore negativity } \\
\text { persists about day labouring. }\end{array}$ \\
\hline Lookfulltime & $\begin{array}{l}\text { Are you looking for a } \\
\text { full-time job? }\end{array}$ & - & $\begin{array}{l}\text { If a day labourer is currently } \\
\text { looking for a full-time job it is } \\
\text { assumed that he or she is } \\
\text { unhappy with his or her } \\
\text { current job situation. }\end{array}$ \\
\hline Turndown & $\begin{array}{l}\text { Have you turned } \\
\text { down a job? }\end{array}$ & - & $\begin{array}{l}\text { A day labourer will turn down } \\
\text { a job when the wage is too low, } \\
\text { leading to further dejection } \\
\text { and despair. }\end{array}$ \\
\hline
\end{tabular}

Source: Blaauw, P.F., Botha, I., Schenck, R. \& Schoeman, C., 2013, 'Happy in the informal economy? A case study of well-being among day labourers in South Africa', International Business \& Economics Research Journal 12(6), 635-654. https://doi.org/10.19030/iber. v12i6.7870

TABLE 10: Comparison variables.

\begin{tabular}{llll}
\hline Variable & $\begin{array}{l}\text { Definition or } \\
\text { question in survey }\end{array}$ & $\begin{array}{l}\text { Expected sign } \\
\text { of coefficient }\end{array}$ & $\begin{array}{l}\text { A priori reasoning for } \\
\text { expected sign }\end{array}$ \\
\hline Jobsbetter & $\begin{array}{l}\text { Are jobs better at } \\
\text { this site? }\end{array}$ & + & $\begin{array}{l}\text { This is a comparison with } \\
\text { himself or herself or with other } \\
\text { day labourers. The possibility } \\
\text { of a better site makes the day } \\
\text { labourer feel better. }\end{array}$ \\
Food & $\begin{array}{l}\text { Do you have enough } \\
\text { food? }\end{array}$ & $\begin{array}{l}\text { If the day labourer had food he } \\
\text { or she would feel more positive } \\
\text { about his or her job } \\
\text { (comparison with himself or } \\
\text { herself or other day labourers). }\end{array}$ \\
& $\begin{array}{l}\text { This is the difference between } \\
\text { income from a good week and } \\
\text { that from a bad week; the sign } \\
\text { therefore depends on whether } \\
\text { the change is negative or } \\
\text { positive. }\end{array}$ \\
\hline
\end{tabular}

Source: Blaauw, P.F., Botha, I., Schenck, R. \& Schoeman, C., 2013, 'Happy in the informal economy? A case study of well-being among day labourers in South Africa', International Business \& Economics Research Journal 12(6), 635-654. https://doi.org/10.19030/iber. v12i6.7870

TABLE 11: Attitudinal variables.

\begin{tabular}{llll}
\hline Variable & $\begin{array}{l}\text { Definition or } \\
\text { question in survey }\end{array}$ & $\begin{array}{l}\text { Expected sign } \\
\text { of coefficient }\end{array}$ & $\begin{array}{l}\text { A priori reasoning for } \\
\text { expected sign }\end{array}$ \\
\hline Injury & $\begin{array}{l}\text { Have you incurred } \\
\text { an injury? }\end{array}$ & - & $\begin{array}{l}\text { If the day labourer incurred } \\
\text { an injury he or she would } \\
\text { probably have a negative } \\
\text { attitude towards his or her } \\
\text { job and situation. }\end{array}$ \\
Support & $\begin{array}{l}\text { Do you have a } \\
\text { support group? }\end{array}$ & + & $\begin{array}{l}\text { If the day labourer is part of a } \\
\text { group of day labourers who } \\
\text { support each other, he or she } \\
\text { would have a positive attitude. }\end{array}$ \\
Stayfamily & $\begin{array}{l}\text { Do you stay with } \\
\text { family? }\end{array}$ & + & $\begin{array}{l}\text { If the day labourer stays with } \\
\text { his or her family it is assumed } \\
\text { that he or she receives family } \\
\text { support. }\end{array}$ \\
\hline
\end{tabular}

Source: Blaauw, P.F., Botha, I., Schenck, R. \& Schoeman, C., 2013, 'Happy in the informal economy? A case study of well-being among day labourers in South Africa', International Business \& Economics Research Journal 12(6), 635-654. https://doi.org/10.19030/iber. v12i6.7870 
The J-statistic probabilities were 0.0 and 0.58 for the objective and subjective functions, respectively. In the case of the objective function, the null hypothesis (exogeneity) was rejected, indicating the endogeneity of the variable.

The log of the lowest wage (LOWWAGE), change in the log of the lowest wage and the number of months working as a day labourer (MONTHS) were used as possible instruments. The orthogonality C-test confirmed the exogeneity of these variables where the probability of the J-statistic was $>0.05$ and showed acceptance of the null hypothesis (exogeneity). The weak instrument test showed that the number of months working as a day labourer was weaker than the other two instruments. The estimation results for the objective function and the subjective function are presented in Table 12.

\section{Objective function results}

Most demographic variables were significant in the 2SLS model, which estimated objective well-being across
South Africa. The twenties age group was significant. The education variables were significant with an unexpected sign for completed secondary school. The economic variables were all significant and the signs were according to expectations, except for previously having a full-time job which recorded a positive sign. Possibly, former full-time workers were more confident of their future prospects at the time of being interviewed as opposed to being dejected or angry about losing their employment status. Only the job opportunity and food variables were significant for the comparison variables - the signs were unexpected. For example, having enough food might reduce the opportunity cost of not standing on the street corner for days on end, leading to less employment and income. This might well be a cyclical and therefore non-linear relationship which needs to be tested in future research. The attitudinal variables were all significant, except for staying with family.

When accounting for the differences in provinces in the sample (2SLS with dummies), the significance of some of the

TABLE 12: Results for the objective and subjective functions.

\begin{tabular}{|c|c|c|c|c|c|c|c|c|c|c|c|c|}
\hline \multirow[t]{2}{*}{ Variable } & \multicolumn{6}{|c|}{ Objective } & \multicolumn{6}{|c|}{ Subjective } \\
\hline & $2 S L S$ & SE & Sig. level & $\begin{array}{c}2 \mathrm{SLS} \\
\text { (dummies) }\end{array}$ & SE & Sig. level & Probit & SE & Sig. level & $\begin{array}{c}\text { Probit } \\
\text { (dummies) }\end{array}$ & SE & Sig. level \\
\hline African & 0.08 & 0.045 & $10 \%$ & -0.001 & -0.022 & - & -0.011 & 0.136 & - & -0.091 & 0.153 & - \\
\hline Primary & 0.142 & 0.050 & $1 \%$ & 0.102 & 2.204 & $5 \%$ & -0.286 & 0.163 & $5 \%$ & -0.306 & 0.167 & $10 \%$ \\
\hline Secondary & 0.247 & 0.047 & $1 \%$ & 0.203 & 4.450 & $1 \%$ & -0.159 & 0.163 & - & -0.194 & 0.168 & - \\
\hline Complete & 0.281 & 0.055 & $1 \%$ & 0.247 & 4.622 & $1 \%$ & -0.12 & 0.181 & - & -0.121 & 0.185 & - \\
\hline Divorced & -0.018 & 0.042 & - & -0.034 & -0.839 & - & 0.103 & 0.161 & - & 0.157 & 0.166 & - \\
\hline Twenties & -0.066 & 0.034 & $10 \%$ & -0.081 & -2.547 & $5 \%$ & -0.195 & 0.107 & $10 \%$ & -0.173 & 0.109 & - \\
\hline Thirties & 0.001 & 0.032 & - & 0.011 & 0.384 & - & -0.123 & 0.115 & - & -0.145 & 0.117 & - \\
\hline Forties & -0.037 & 0.037 & - & -0.039 & -1.151 & - & 0 & 0.126 & - & -0.026 & 0.127 & - \\
\hline Over50 & -0.051 & 0.057 & - & -0.034 & -0.652 & - & -0.161 & 0.192 & - & -0.208 & 0.195 & - \\
\hline \multicolumn{13}{|l|}{ Economic } \\
\hline Log (goodweek) & 0.603 & 0.031 & $1 \%$ & 0.377 & 8.367 & $1 \%$ & 0.759 & 0.073 & $1 \%$ & 0.778 & 0.081 & $1 \%$ \\
\hline Looking & -0.113 & 0.049 & $5 \%$ & -0.094 & -1.924 & $10 \%$ & -0.009 & 0.186 & - & -0.049 & 0.187 & - \\
\hline Turndown & -0.066 & 0.031 & $5 \%$ & -0.038 & -1.250 & - & -0.034 & 0.099 & - & -0.032 & 0.101 & - \\
\hline \multicolumn{13}{|l|}{ Comparison } \\
\hline Jobopp & -0.089 & 0.035 & $5 \%$ & 0.014 & 0.364 & - & 1.78 & 0.078 & $1 \%$ & 1.726 & 0.080 & $1 \%$ \\
\hline Food & -0.132 & 0.047 & $1 \%$ & 0.016 & 0.344 & - & 0.559 & 0.074 & $1 \%$ & 0.571 & 0.077 & $1 \%$ \\
\hline Dlog (goodweek) & 0.015 & 0.021 & - & 0.017 & 0.805 & - & -0.192 & 0.059 & $1 \%$ & -0.204 & 0.061 & $1 \%$ \\
\hline \multicolumn{13}{|l|}{ Attitudes } \\
\hline Injury & -0.108 & 0.030 & $1 \%$ & -0.091 & -3.104 & $1 \%$ & 0.013 & 0.104 & - & 0.085 & 0.107 & - \\
\hline Support & 0.145 & 0.022 & $1 \%$ & 0.142 & 6.781 & $1 \%$ & -0.111 & 0.080 & - & -0.14 & 0.084 & $10 \%$ \\
\hline Stayfamily & 0.022 & 0.022 & - & 0.041 & 1.974 & $5 \%$ & -0.087 & 0.073 & - & -0.105 & 0.077 & - \\
\hline c & 0.878 & 0.209 & $1 \%$ & - & - & - & -4.641 & 0.522 & $1 \%$ & - & - & - \\
\hline \multicolumn{13}{|l|}{ Community } \\
\hline Gauteng & - & - & - & 2.166 & 8.093 & $1 \%$ & - & - & - & -4.358 & 0.584 & $1 \%$ \\
\hline Mpumalanga & - & - & - & 2.003 & 7.595 & $1 \%$ & - & - & - & -4.521 & 0.588 & $1 \%$ \\
\hline Limpopo & - & - & - & 2.195 & 8.957 & $1 \%$ & - & - & - & -4.667 & 0.617 & $1 \%$ \\
\hline North West & - & - & - & 2.06 & 8.015 & $1 \%$ & - & - & - & -4.233 & 0.586 & $1 \%$ \\
\hline Free State & - & - & - & 2.033 & 8.019 & $1 \%$ & - & - & - & -4.534 & 0.563 & $1 \%$ \\
\hline Northern Cape & - & - & - & 2.018 & 7.946 & $1 \%$ & - & - & - & -4.544 & 0.542 & $1 \%$ \\
\hline Western Cape & - & - & - & 2.45 & 8.373 & $1 \%$ & - & - & - & -4.719 & 0.594 & $1 \%$ \\
\hline Total observations & 2645 & - & - & 2636 & - & - & 2645 & - & - & 2636 & - & - \\
\hline Adjusted $R^{2}$ & 0.46 & - & - & 0.52 & - & - & 0.55 & - & - & 0.42 & - & - \\
\hline SE of regression & 0.39 & - & - & 0.37 & - & - & 0.3 & - & - & 0.3 & - & - \\
\hline
\end{tabular}

Sig. level, significance level; 2SLS, two-stage least-squares; SE, standard error; C, orthogonality C-test. 
variables changed. Most of the variables that were significant in the 2SLS model were still significant with the same sign, except for the economic variable turned down a job which became insignificant, and the comparison variables having food and better job opportunities at this site became insignificant. The attitudinal variable, staying with family, became significant. All the economic and attitudinal variables became significant (except turned down a job) in the dummy variable model. The dummy variables for the nine provinces indicating the geographical links and community variables were all significant. This shows that there were significant differences between the provinces and it confirms the importance of community variables as explanatory variables for well-being functions. The bigger size effects for provinces such as the Western Cape and Gauteng possibly reflected their status as the powerhouse economic regions in South Africa.

\section{Subjective function results}

The subjective function was first modelled using the probit model to estimate subjective well-being in South Africa, while the second probit model used dummy variables to account for the differences between the provinces in South Africa. The results of the two models were very similar. Only gender, primary schooling and the twenties age group (only in the first probit) were significant. The economic variables, income and whether the participant previously had a fulltime job were significant with the expected sign. All the comparison variables were significant with the expected sign. No attitudinal variables were significant, except for the support variable in the dummy variable model with an unexpected sign. The support variable was only significant at the $90 \%$ confidence level and might reflect the fact that day labourers saw the need for support as detracting from their perceptions of their own capabilities and levels of agency.

The dummy variables for the nine provinces indicating the geographical links and community variables were all significant. This shows that there were significant differences between the provinces and also confirms the importance of community variables as explanatory variables for well-being functions. The negative signs in the case of the subjective function might reflect the disappointment linked to anticipated better opportunities in the migrant destination provinces as well as the prevailing negative perceptions in the poorer provinces from which the migrants originated.

Comparing the objective and subjective functions, there were clear differences in the results. The attitudinal variables were significant in the objective function, whereas comparison variables were significant in the subjective function. The economic variables were significant in both functions; however, only two of the four variables were significant in the subjective function. This confirms what the literature says about income being an important factor in determining wellbeing within poor communities.

The objective function was mainly driven by the tangible aspects of day labouring, such as staying with family, injuries occurring and being part of a support group, while the dependent variable was the actual income. The subjective function was mainly driven by comparison variables, including whether there were better job opportunities at the site, whether day labourers had enough food and changes in income. These variables were based more on perceptions and the function's dependent variable was based on income expectations. The community variables and the dummy variables for the provinces were significant in both functions. The objective function's coefficients were positive and indicated that the provinces differed in terms of income (Knight et al. 2009). The subjective function's coefficients were negative, showing that perceptions of well-being had a negative impact on subjective well-being - which was in contrast to the positive impact on well-being in the objective function. This possibly also explained the different signs for the full-time job variable in the two functions. This is because the perception of a full-time job was negatively perceived in terms of subjective well-being, in contrast to the positive sign in the objective function, which was linked to a certain income rather than the perception.

Mulcahy and Kollamparambil (2016) found that rural-tourban migration has a negative impact on subjective wellbeing in South Africa due to unmet expectations and aspirations, and emotional fallout. For day labourers in South Africa, this may also be the case. The richer provinces have more job opportunities but also more competition, and therefore the income may not be as good as day labourers expect. This is supported by the evidence presented in a study by Krugell and Blaauw (2011): in metropolitan areas, greater occupation density was negatively associated with the earnings of day labourers, which reflected the competition for jobs among day labourers in the big cities. A general increase in the number of day labourers in South Africa's major cities since the global economic downturn and slower growth in the construction industry have given rise to even greater competition.

\section{Key conclusions}

Objective and subjective well-being functions were used to determine whether the well-being of day labourers in South Africa differed from one province to the next. The literature revealed broad categories of determinants (economic, comparison, attitudinal and communities) that influence well-being in general.

The findings from this study confirmed that economic variables do play a role in both measures of well-being, and that attitudinal and comparison variables are significant in the objective and subjective measures of well-being, respectively. The results resonate with the work of Sen $(1999,2003)$. Income is a leading indicator of capability among day labourers. It allows them to provide for their dependants and to exercise agency in an often unforgiving labour market environment.

The findings also confirmed that geographical links and community variables are significant in both functions, indicating that well-being is statistically different between 
the provinces. This seems a plausible result, given that migration to provinces that are doing better economically can potentially add to the freedom and capabilities enjoyed by day labourers. To reiterate, it is the agency that day labourers display in leaving family and familiar surroundings behind in search of better opportunities that makes such benefits possible. However, on a subjective level, these potential gains are to a large extent negated by increased levels of competition and an oversupply of day labourers in most urban labour markets. This often leaves day labourers disappointed with the returns from their 'agency investment', so to speak.

Furthermore, the impact of the community variables on the well-being of day labourers differs between the objective and subjective functions, confirming the importance of the measures of well-being. The impact of community variables on well-being for the objective function was positive due to its direct link to income, as opposed to the negative impact for the subjective function because of the subjective nature of perceptions. Moreover, these findings are linked to the different degrees of prominence of the attitudinal and comparison determinants of well-being between these functions.

\section{Avenues for further research}

On a methodological level, the results open up new avenues for refining the study of subjective well-being as it relates to the informal economy. The question arising from the application of Sen's CA is the extent to which it is not the income per se that influences the level of subjective wellbeing but rather what people can afford with the income and the welfare difference they feel afterwards (such as freedom from hunger and other forms of marginalisation) that determine their levels of subjective well-being. Although the literature supports income as a measure of objective wellbeing, it cannot speak to the capabilities, functionings and freedoms it brings. Measuring the dimensions of subjective well-being is the methodological challenge for future research flowing from this study.

Well-being in the informal economy is a multifaceted phenomenon. It is imperative to use both the objective and subjective measures of well-being when dealing with wellbeing among day labourers and, by implication, other marginalised groups. For many vulnerable groups such as day labourers, waste pickers and car guards, the informal economy offers both opportunities and certain freedoms to the unemployed. Even with limited capabilities, these people are able to access work and income through some form of agency. This offers them at least some self-respect and provides an alternative to a life of begging or, worse, crime. A day labourer in Port Elizabeth summed it up very well: 'We cannot sit at home and watch the hungry family'.

Finding ways to enhance and deepen the agency and capabilities offered by the informal economy will provide an important new field of research for academics and other research professionals. This in turn will lay the foundation for more robust urban and social development policies and implementation plans in South Africa, and strengthen hopes for a much more equal society.

\section{Acknowledgements}

The authors want to acknowledge the valuable comments and suggestions received from Prof. John Luiz as well as the anonymous referees of the journal. The same applies to the contribution in terms of editing by Ms Ali Parry. The manuscript benefitted significantly from this. All mistakes remain our own. Funding for the project was provided by the National Research Foundation (NRF).

\section{Competing interests}

The authors declare that they have no financial or personal relationships that may have inappropriately influenced them in writing this article.

\section{Authors' contributions}

P.F.B. was jointly responsible for the conceptualising of the research project, participated in the fieldwork and acted as first author on the various drafts of the article. I.B. assisted in the conceptualising of the article, handled the econometric modelling, and acted as second author on the various drafts of the article. C.S. assisted in the conceptualising of the research project, participated in the fieldwork and acted as third author on the various drafts of the article.

\section{References}

Alatartseva, E. \& Barysheva, G., 2015, 'Well-being: Subjective and objective aspects', Procedia - Social and Behavioral Sciences 166(2015), 36-42. https://doi.org/ 10.1016/j.sbspro.2014.12.479

Alkire, S. \& Deneulin, S., 2002, 'Individual motivation, its nature, determinants and consequences for within group behaviour', in J. Heyer, F. Stewart \& R. Thorp (eds.), Group motivation and development: Is the market destroying cooperation?, pp. 59-74, Oxford University Press, Oxford.

Biswas-Diener, R. \& Diener, E., 2001, 'Making the best of a bad situation: Satisfaction in the slums of Calcutta', Social Indicators Research 55(3), 329-352. https://doi. org/10.1023/A:1010905029386

Blaauw, D., Louw, H. \& Schenck, R., 2006, 'The employment history of day labourers in South Africa and the income they earn: A case study of day labourers in Pretoria', South African Journal of Economic and Management Sciences 9(4), 458-471. https://doi.org/10.4102/sajems.v9i4.1034

Blaauw, P.F., 2010, 'The socio-economic aspects of day labouring in South Africa', PhD thesis, Department of Economics \& Econometrics, University of Johannesburg.

Blaauw, P.F., Botha, I., Schenck, R. \& Schoeman, C., 2013, 'Happy in the informal economy? A case study of well-being among day labourers in South Africa', International Business \& Economics Research Journal 12(6), 635-654. https://doi. org/10.19030/iber.v12i6.7870

Blaauw, P.F., Pretorius, A.M., Schenck, C.J. \& Viljoen, J.M.M., 2015, 'The subjective well-being of waste pickers in the Free State province of South Africa', paper presented at the 10th International Conference on Interdisciplinary Social Sciences, Split, Croatia, 10-14th June.

Botha, F. \& Booysen, F., 2013, 'The relationship between marital status and life satisfaction among South African adults', Acta Academica 45(2), 150-178.

Brooks, C., 2008, Introductory econometrics for finance, Cambridge University Press, New York.

Cramm, J.M., Møller, V. \& Nieboer, A.P., 2010, 'Improving subjective well-being of the poor in the Eastern Cape', Journal of Health Psychology 15(9), 1012-1019. https:// doi.org/10.1177/1359105310367833

Cummins, R.A., 2000, 'Personal income and subjective well-being: A review', Journa of Happiness Studies 1, 133-158. https://doi.org/10.1023/A:1010079728426

De Vos, A.S., Strydom, H., Fouche, C.B. \& Delport, C.S.L., 2004, Research at the grass roots: For the social sciences and human service professions, 2 nd edn., Van Schaik, Pretoria.

Diener, E., Oishi, S. \& Lucas, R.E., 2002, 'Subjective well-being: The science of happiness and life satisfaction', in C.R. Snyder \& S.J. Lopez (eds.), Handbook of positive psychology, pp. 63-73, Oxford University Press, Oxford. 
Diener, E., Sandvik, E., Seidlidtz, L. \& Diener, M., 1993, 'The relationship between income and subjective well-being: Relative or absolute?', Social Indicators Research 28, 195-223. https://doi.org/10.1007/BF01079018

Dolan, P., Peasgood, T. \& White, M., 2008, 'Do we really know what makes us happy? A review of the economic literature on the factors associated with subjective wellbeing', Journal of Economic Psychology 29, 94-122. https://doi.org/10.1016/j. joep.2007.09.001

Ebrahim, A., Botha, F. \& Snowball, J., 2013, 'Determinants of life satisfaction among race groups in South Africa', Development Southern Africa 30(2), 168-185. https://doi.org/10.1080/0376835X.2013.797227

Frey, B. \& Stutzer, A., 2002, 'What can economists learn from happiness research?', Journal of Economic Literature 40, 402-435. https://doi.org/10.1257/jel.40.2.402

Gonzo, W. \& Plattner, I.E., 2003, Unemployment in an African country: A psychological perspective, University of Namibia Press, Windhoek.

Harmse, A., Blaauw, P.F. \& Schenck, R., 2009, 'Day labourers, unemployment and socio-economic development in South Africa', Urban Forum 20(4), 363-377. https://doi.org/10.1007/s12132-009-9067-8

Hirata, J., 2011, Happiness, ethics and economics, Routledge, New York.

Kingdon, G.G. \& Knight, J., 2004, Subjective well-being poverty versus income poverty and capabilities poverty, WPSO03, Economic and Social Research Council, Swindon.

Knight, J. \& Gunatilaka, R., 2008, Aspirations, adaption and subjective well-being of rural-urban migrants in China, Discussion Paper No. 381, Department of Economics, University of Oxford, Oxford.

Knight, J., Song, L. \& Gunatilaka, R., 2009, 'Subjective well-being and its determinants in rural China', China Economic Review 20, 635-649. https://doi.org/10.1016/j. chieco.2008.09.003

Krugell, W.F. \& Blaauw, P.F., 2011, 'Micro-evidence on day labourers and the thickness of labour markets in South Africa', paper presented at the 4th Public Economics Workshop, hosted by Economic Research Southern Africa (ERSA), Stellenbosch Workshop, hosted by Economic Research Southern Africa (ERSA), Stellenbosch
Institute for Advanced Study (STIAS), University of Stellenbosch, Stellenbosch, 3-4

Mulcahy, K. \& Kollamparambil, U., 2016, 'The impact of rural-urban migration on subjective well-being in South Africa', Journal of Development Studies 52(9), 1357-1371. https://doi.org/10.1080/00220388.2016.1171844
Robeyns, I., 2005, 'The capability approach: A theoretical survey', Journal of Human Development 6(1), 93-114. https://doi.org/10.1080/146498805200034266

Robeyns, I., 2006, 'The capability approach in practice', Journal of Political Philosophy 17(3), 351-376. https://doi.org/10.1111/j.1467-9760.2006.00263.x

Rubin, A. \& Babbie, E., 1997, Research methods for social work, 3rd edn., Brooks Cole, Pacific Grove.

Saunders, S.G., 2005, 'Estimates of the informal economy in South Africa: Some macroeconomic policy implications', PhD thesis, Department of Economics \& Econometrics, University of Johannesburg.

Sen, A., 1999, Development as freedom, Oxford University Press, Oxford.

Sen, A., 2003, 'Capability and well-being', in M. Nussbaum \& A. Sen (eds.), Quality of life, pp. 30-53, Oxford University Press, Oxford.

Senik, C., 2005, 'Income distribution and well-being: What can we learn from subjective data?', Journal of Economic Surveys 19(1), 43-63. https://doi.org/10.1111/j.09500804.2005.00238.x

Statistics South Africa, 2006, Mid-year population estimates, South Africa 2006 viewed 13 August 2016, from http://www.statssa.gov.za/publications/P0302/ P03022006.pdf

Statistics South Africa, 2014, Poverty trends in South Africa: An examination of absolute poverty between 2006 and 2011, viewed 04 January 2018, from http://beta2. statssa.gov.za/publications/Report-03-10-06/Report-03-10-06March2014.pdf

Statistics South Africa, 2015, National and provincial labour market: Youth, viewed 04 January 2018, from http://www.statssa.gov.za/publications/P02114.2/P02114. 22015.pdf

Theodore, N., Blaauw, D., Schenck, C., Valenzuela, A. Jr, Schoeman, C. \& Meléndez, E., 2015, 'Day labor, informality and vulnerability in South Africa and the United States', International Journal of Manpower 36(6), 807-823. https://doi.org/ 10.1108/IJM-01-2014-0036

Theodore, N., Valenzuela, A. Jr. \& Meléndez, E., 2009, 'Worker centers: Defending labor standards for migrant workers in the informal economy', International Journal of Manpower 30(5), 422-436. https://doi.org/10.1108/01437720910977634

Valenzuela, A. Jr., Theodore, N., Meléndez, E. \& Gonzalez, A.L., 2006, On the corner: Day labor in the United States, UCLA, Los Angeles, CA. 